\title{
Evaluation on the Development Mode and Process of Modernized Education in China
}

\author{
Dan $\mathrm{Wu}$ \\ North China University of Technology \\ Beijing, China
}

\begin{abstract}
Modernized education is an important supporting part for accelerating the construction of a modernized country. Based on references available at home and abroad, this author collects and borrows modernized education evaluation systems in all aspects. Based on the achievements, first, this article analyzes development mode of modernized education, detailing main characteristics and changes of modernized education process; second, it makes a systematic design of modernized education indices system to evaluate the overall process of modernized education from educational development level, educational condition and teaching faculties. Research results show, nature of modernized education is to continuously improve three-level enrollment rate, and China has made obvious progress in modernized education, reaching $90 \%$. During the 13th five-year plan, senior high school education and higher education are accelerated to promote the upgrade of educational development strategy, and it is predicted that China will have its modernized education goal achieved by 2020 or earlier.
\end{abstract}

Keywords-modernized education; development mode; characteristics; process; evaluation indices

\section{INTRODUCTION}

Education is a necessity for the people, a basic way to continuously improve human capital level and a significance security for national economy and social development. The Outline of National Medium-and Long-Term Program for Education Reform and Development (2010-2020) points out that main educational indices in China shall reach the level of moderately developed countries by 2020 , conducts overall layout and strategic arrangement on basic completion of modernized education. The 13th five-year plan for national economy and social development clearly points out that laborers shall have their education period increased obviously during the period, all of the measures have made great preparations for realizing a modernized country. To study the development mode of modernized education and make an overall evaluation on the modernized education process will have great significance in theory and practice for establishing and perfecting education development mechanism and accelerating the modernized education, which has become a hot topic in Chinese education circle and academic field.

Organization for Economic Co-operation and Development

Projects Supported by National Natural Science Foundation for Youth (71603004), Projects Supported by Beijing Social Science Foundation for Youth (17GLC064), Projects Supported by North China University for Distinguished Talents Cultivation Program (XN018035)
(OCED), United Nations Educational, Scientific and Cultural Organization (UNESCO) and World Bank (WB) worked out successively index classification standards and index system used to evaluate modernized education, which are taken as references in most countries around the world. Among them, the OCED raises three evaluation systems respectively in 1997 2000 and $2003^{[1]}$, continuously increasing connotation of modernized education and perfecting modernized education evaluation system, which provided powerful support for supervising modernized education process and making educational policies; the UNESCO worked out modernized education evaluation indices ${ }^{[2]}$, aiming to the influence of education on society, politics, economy, culture and population, the WB released a World Development Indices (Report) per year since the $1980 \mathrm{~s}$, taking modernized education as one of the key parts, specially indicating the educational input-output efficiency ${ }^{[3]}$.

Most scholars in Chinese educational circles and academic fields started deep researches on modernized education theories and practices from the middle 1980s, achieving a lot. With regards to modernized education theoretical researches, the core of modernized education is to build and perfect modernized education systems, including modernized educational framework system and modernized education evaluation system. Modernized educational framework system mainly includes modernized educational concepts, modernized educational contents and faculties, modernized educational technologies and modernized educational management and so on ${ }^{[4-8]}$; Modernized educational evaluation system shall include not only evaluation systems at state and provincial levels but also evaluation systems of higher education, fundamental education, vocational education and so on. It is focused on taking modernized education goals, index systems and evaluation standards as core research fields and closely combining with educational practice and educational work ${ }^{[9-12]}$ For example, scholars such as Tan Songhua, et $\mathrm{al}^{[9]}$, based on three steps strategic conception raised by Deng Xiaoping in the 1980s, designed modernized education measuring standards for primary, medium and advanced stages; Li Jianning, et al ${ }^{[10]}$ took educational quality and fair education as key points for evaluation, creating a modernized education index system framework and policy tool matrix on the basis of the pressurestatus-response framework model; Dong Yan, et $\mathrm{al}^{[11]}$ put the modernized education supervision and evaluation on eight points including educational conceptions, system construction, input guarantee, management systems, educational spread, 
educational quality, fair education and service contribution, conducting top-level design on modernized education evaluation indices; Zhang $\mathrm{Li}$, et $\mathrm{al}^{[12]}$ raised quantitative standards for modernized education index system.

Based on modernized education practice and exploration, a great number of scholars analyzed the history of Chinese modernized education, detailing its characteristics and evaluating at different levels ${ }^{[3-18]}$. For example, Tian Zhengping, et $\mathrm{al}^{[14]}$ deeply analyzed the structural changes of educational systems, discussing the educational system innovation and drive mechanism of modernized education since China's opening up; Tan Songhua ${ }^{[15]}$ analyzed regional characteristics and conditions to realize modernized education, regional harmonious development strategy and strategies to drive regional modernized education, and the educational development in 31 provinces in the country were borrowed to show regional modernized education process; Hu Angang ${ }^{[17-18]}$ conducted interim evaluation on the educational development during the 12th five-year plan, analyzing the overall goal and main tasks for the 13th five-year plan and overlooking the modernized educational process from 2015 to 2030. In addition, National Center for Education Development Research released a Modernized Education Supervision Evaluation and Comparative Research Report in 15 SubProvincial City $(2014)^{[19]}$ in 2014, based on education development index, fair education index, educational conditions and security index, modernized education management index and so on, the modernized education levels of 15 sub-provincial cities were evaluated, which provide references for decision making on modernized education systems in the country and 15 sub-provincial cities.

Due to modernized education theory researches and practical exploration results, 7 quantitative indices, including literacy rate of population aged 15 or more, average predicted training period, gross enrollment rate of secondary education, gross enrollment rate of higher education, number of college students per ten thousand persons, proportion of public educational fund in GDP, per capita public educational fund, have become key indices to measure modernized education. Core researches in modernized education evaluation are focused on educational spread, educational quality, and educational security and so on. However, the design of domestic scholars about modernized education evaluation system is unable to recognize the nature of modernized education on the basis of overall development of state modernization, having no framing concepts guiding the whole index system. Accordingly based on the strategic goal of boosting the state modernized education, it needs to systematically design the framing concept system of modernized education development, analyze the development modes of modernized education and card main characteristic changes in the course of evolution of modernized education. Considering the educational development level, educational conditions security and faculty team construction, it needs to systematically design evaluation index for modernized education and overall evaluate the realization degree of modernized education.

\section{DEVELOPMENT MODES FOR MODERNIZED EDUCATION}

Generally education is divided into three stages namely primary education, middle school education (including junior high school education and senior high school education), and modernized education is a dynamic development course, which follows the world modern education development and goes from low level to high level, stressing to consider the harmonious development between education, economy and society wholly and systematically. The nature of modernized education is a course where the enrollment rate is being upgraded in three stages. It aims to boost the upgrading of state human resources development level and provide basic human capital for the state construction of modernization.

Modernized education mainly undergoes five stages: primary education period, primary education rapid spread period, secondary education rapid spread period, higher education rapid spread period and higher education mature spread period. Among them (1) The primary education period has lowered enrollment rate of three-level education; (2)The primary education rapid spread has rapid rise of enrollment rate of primary education, and slow rise of enrollment rate of middle school education, very lower enrollment rate of higher education; (3) The middle school education rapid spread period has basic spread of primary education, rapid rise of enrollment rate of middle school education, slow rise of enrollment rate of higher education, yet low in spread; (4)The higher education rapid spread stage has spread of primary education and junior high school education, and basic spread of senior high school. In the meantime, the enrollment rate of higher education rises rapidly; (5) The higher education mature spread stage has spread of primary education and middle school education, and higher education is in a steady high level.

Nowadays, Chinese modernized education has undergone three stages, whose main characteristics mainly include:

(1) Primary education period (1949 through 1952), the economy development relied on agriculture with industrialization started initially, the people lived with very low income, poor education as well as low demand in education and purchasing power.

It is estimated by Angus Maddison that the students receiving higher education totaled 31,000 in $1937,117,000$ in 1949 , and the students receiving secondary education totaled 1.268 million in 1949 , equal to $2.3 \%$ of the total population. There were 320 million persons who were uneducated or semiuneducated in China in $1949,80 \%$ of a total population of 550 million in the country. 1 The average education year of laborers was one year, equal to $1 / 3-1 / 2$ of the world average level, which was obviously lower than the world average level. In 1950, the education year of laborers in China was 1.6 years, yet the average education year of laborers in the UK and the

${ }^{1}$ Li Yuming, State Fate Related to Knowledge [N].Guangming Daily, Oct 1, 2009.

http://www.gmw.cn/01gmrb/2009-10/01/content_990236.htm. 
US, had reached 10.6 and 11.27 years respectively, which was 6.6 and 7 times that in China. ${ }^{2}$

(2) Primary education rapid spread period (1952 through 1980), the economic development entered a stage of rapid industrialization, with higher industry rate, lower income of the people and improved educational level.

Up to 1978 , China had established a complete range of education system. On the one hand, basic spread of primary education: from 1952 to 1978 , the enrollment rate of school age children rose from $49.20 \%$ to $95.90 \%$ in the country; on the other hand, elimination of most people who were uneducated or semi-educated, un-education rate lowered rapidly: In 1964, the population of the uneducated or semiuneducated was reduced to 233 million, and 230 million in 1982; and the un-education rate of adult was greatly reduced form $80 \%$ in 1949 to $33.50 \%$ in 1964 , and $22.81 \%$ in 1982 , and China was one of the rapidest countries in elimination of un-education rate. In the meantime, the education year of laborers was increased obviously, 2.0, 3.2 and 5.33 years increased in 1960, 1970 and 1980 respectively.

In addition, higher education went fluctuating. From 1949 to 1959 was the first gold period of higher education development in China, there were about 1 million college students in 1959; from 1960 to 1963 , due to the failure of Great Leap Forward, the natural economy was suspended in stagnation, and the number of college students was greatly lowered. During the Great Cultural Revolution period, from 1966 to 1969 , higher education institutions stopped admission, and college students were in a sharp reduction, about 48,000 students left in 1970. Mao Zedong raised "Workers, farmers, soldiers and trainees should receive college education", some colleges started admission from workers, farmers and soldiers who had experience in practice and youth going countryside according to "recommendation by the people, approval by leaders and review by colleges". However, up to 1976, the number of college students was still lower than that in 1959. Up to 1978 , there were 856,000 students studying in colleges.

(3) Middle school education rapid spread period (1980 through 2020), sustainable and rapid economic development, obvious improvement of the living level of the people, high increase in educational demand and payment. Among it, during the period from 1980 to 2000 , the country achieved the middle school education rapid spread, from 2000 to 2020 is the middle school education rapid spread middle and later period.

1) Middle school education rapid spread earlier period (1980 through 2000), the economic development was in a period of industrial acceleration, the living level of the people was in a lower and middle income period, further increase in educational demand and purchasing power.

\footnotetext{
2 According to the methods of Angus Maddison, the weight of primary education is 1, 1.4 for middle school education, 2 for higher education. According to his calculation, in 1950, the average education year of Chinese people aged 15-64 in China was 1.60 years. The average education year of people in US, France, Germany and Japan was 11.27, 9.58, 10.40 and 9.11 years respectively.

Angus Maddison,2007, Chinese Economic Performance in the Long

Run,960-2030 AD, Second Edition, Paris, OECD.
}

In the 1980s, Chinese governments raised to rapidly boost the "nine-year compulsory education". From 1980 to 2000, the CPC Central Committee and the State Council held national educational work conferences in 1985, 1994 and 1999 respectively, steadily driving the educational system reform. Seen from the development of primary education and middle school education, the net enrollment rate of primary school age children rose from $95.5 \%$ in 1978 to $99.1 \%$ in 2000 ; the gross enrollment rate of the junior middle school rose from $66.7 \%$ in 1990 to $88.6 \%$ in 2000 , which proved that up to 2000 , China had achieved the goal of basic nine-year compulsory education and basic elimination of uneducated adults, and the population of "nine-year compulsory education" occupied $85 \%$, and the un-education rate of adults was reduced to $5 \%$ or below, and the population of un-educated adults was reduced by 41 million compared to that in 19903. The gross enrollment rate of senior high school rose from $21.9 \%$ in 1990 to $42.8 \%$ in 2000. 4 From 1990 to 2000, the population of senior high school education in China rose from 91.47 million to 140.7 million, increased by $53 \%$.

Seen from the higher education development, college students rose from 856,000 in 1978 to 5.56 million in 2000, 6.5 times that in 1978, and the average growth rate per year reached $8.9 \%$. In the meantime, the gross enrollment of higher education rose from less than $1 \%$ in 1978 to $12.5 \%$ in 2000.5 In addition, from 1990 to 2000 , the population with college degree or above rose from 16 million to 45.63 million, up 1.85 times. After 1980 , the average period of laborers in China exceeded the world average level, higher that the average level of developing countries, which reached 6.43 years in 1990 , 7.86 and 9.9 years in 2000 and 2010 respectively.

2) Middle school education rapid spread mid-later period (2000 through 2020), the economic development enters a mature industrialization period, the proportion of service industry starts to rise, the living level of the people starts to transit from low and middle income to middle income, and the educational demand and purchasing power improve obviously.

The Law on Compulsory Education was modified and released in 2006, the compulsory education turned to free education, The pre-school gross enrollment rate increased rapidly, which reached $70.5 \%$ in $2014,75 \%$ in 2015 , close to the predicted goal for $2020(80 \%)$ raised in the Outline of National Medium-and Long-Term Program for Education Reform and Development (2010-2020). At the end of the 12th five-year plan, the net enrollment rate of primary school children increased to $99.88 \%$.

In 2010, the gross enrollment rate of middle school education was $81 \%$, ranking ahead in developing countries. And the population receiving senior high school education increased to 188 million in China. At the end of the 12th fiveyear plan, the gross enrollment rate of junior middle school

${ }^{3}$ Chen Zhili, Actually Implement the Strategic Position of Prior Education Development, carried in Tutoring Books for the Report at the $16^{\text {th }}$ Party Congress, pp 321-322, Beijing, People's Publishing House, 2002.

${ }^{4}$ China Statistics Abstract (2009), written by State Bureau of Statistics of the PRC, pp 185, pp190, Beijing, China Statistics Press, 2009.

${ }^{5}$ China Statistics Abstract (2009), written by State Bureau of Statistics of the PRC, pp190, Beijing, China Statistics Press, 2009. 
rose to $104 \%$ in China, and the gross enrollment rate of senior high school rose by $87 \%$, achieving the goal (87\%) set in the 12th five-year plan. In addition, "retention rate of nine-year compulsory education" was taken as a new index in the 12th five-year plan to measure the educational development level in China. In 2015, the retention rate of nine-year compulsory education reached $93 \%$, achieving the goal set in the 12th fiveyear plan, close to the predicted goal for 2020 (95\%) raised in the Outline.

In 2015, the average education year of laborers in China rose to 10.23 years from 9.9 years in 2010. The population with college degree or above reached 170.93 million, and college students reached 36.47 million, exceeding the predicted goal (33 million) for 2020 raised in the Outline. Seen from the gross enrollment rate of higher education, it reached
$26.5 \%$ in 2010 , up to $34.5 \%$ in $2013,40 \%$ in 2015 , exceeding the predicted goal $(36 \%)$ raised in the 12 th five-year plan, close to $50 \%$ set in 2020 state middle and long term education layout.

\section{EVALUATION ON MODERNIZED EDUCATION PROCESS}

According to the modernized education development modes, considering the practical exploration and experience in modernized education in developed countries and developed provinces in China, as far as educational development level, educational condition security and faulty team construction, based on primary education, middle school education and higher education, we here create a core index system for modernized education evaluation, refer to "Table I".

TABLE I. CORE INDEX SYSTEM FOR MODERNIZED EDUCATION

\begin{tabular}{|c|c|c|}
\hline Level I Index & Level II Index & \begin{tabular}{|l} 
Level III Index \\
\end{tabular} \\
\hline \multirow[t]{2}{*}{$\begin{array}{c}\text { Educational } \\
\text { development level }\end{array}$} & Educational spread & $\begin{array}{l}\text { Kindergarten enrollment rate for three-year preschool education }(\%) \\
\text { Net enrollment rate of primary education }(\%) \\
\text { Gross enrollment rate of junior middle school education }(\%) \\
\text { Gross enrollment rate of senior high school education }(\%) \\
\text { Gross enrollment rate of higher education }(\%) \\
\text { Number of college students (unit: ten thousand) } \\
\text { Average education year of laborers (year) }\end{array}$ \\
\hline & Educational completion retention & $\begin{array}{l}\text { Enrollment rate of primary school graduates }(\%) \\
\text { Enrollment rate of junior high school graduates }(\%) \\
\text { Enrollment rate of senior high school graduates }(\%) \\
\text { Nine-year compulsory education retention rate }(\%)\end{array}$ \\
\hline \multirow[b]{2}{*}{$\begin{array}{c}\text { Educational condition } \\
\text { security }\end{array}$} & Educational fund input & $\begin{array}{l}\text { Proportion of educational fund in GDP }(\%) \\
\text { Proportion of state financial educational fund in GDP }(\%) \\
\text { Proportion of public financial educational expenditure in financial expenditure }(\%)\end{array}$ \\
\hline & Educational information & $\begin{array}{l}\text { Proportion of schools equipped with standard facilities for primary education (\%) } \\
\text { Proportion of schools equipped with standard facilities for junior high school } \\
\text { education (\%) } \\
\text { Proportion of schools equipped with standard facilities for senior high school } \\
\text { education }(\%)\end{array}$ \\
\hline \multirow[b]{2}{*}{$\begin{array}{l}\text { Faculty team } \\
\text { construction }\end{array}$} & Faculty input & $\begin{array}{l}\text { Teacher-student ratio in primary education } \\
\text { Teacher-student ratio in junior high school education } \\
\text { Teacher-student ratio in senior high school education } \\
\text { Teacher-student ratio in higher education }\end{array}$ \\
\hline & Teachers' educational background & $\begin{array}{l}\text { Qualification rate of full-time teacher in educational background for primary } \\
\text { education }(\%) \\
\text { Qualification rate of full-time teacher in educational background for junior high } \\
\text { school education }(\%) \\
\text { Qualification rate of full-time teacher in educational background for senior high } \\
\text { school education }(\%)\end{array}$ \\
\hline
\end{tabular}

According to "Table I" Core index system for modernized education, we adopt level equal proportion weighting method and goal consistency method to evaluate the educational development level, educational condition security and faculty team construction from 2000 to 2025 , based on which, we make a comprehensive evaluation on the basic modernized education from 2000 to 2015 . Reference values of all indices can be set according to status quo of Chinese educational development, the Outline, the 13th five-year plan for national economy and social development. With regards to the modernized goal values not given in the Outline and the 13th five-year plan, the average level data of educational development in developed countries can be used as reference, which are sourced from OECD (2010) educational evaluation on developed countries. Reverence values for evaluation index of basic modernized education from 2000 to 2015 and reference value for evaluation index of 2020 can be seen in "Table II". 
TABLE II. REVERENCE VALUES FOR EVALUATION INDEX OF BASIC MODERNIZED EDUCATION FROM 2000 TO 2015

\begin{tabular}{|c|c|c|c|c|c|c|c|}
\hline $\begin{array}{l}\text { Level I } \\
\text { Index }\end{array}$ & $\begin{array}{c}\text { Level II } \\
\text { Index }\end{array}$ & Level III Index & 2000 & 2005 & 2010 & 2015 & $\begin{array}{c}2020 \\
\text { (reference value) }\end{array}$ \\
\hline \multirow{11}{*}{$\begin{array}{l}\text { Educational } \\
\text { development } \\
\quad \text { level }\end{array}$} & \multirow{7}{*}{$\begin{array}{l}\text { Educational } \\
\text { spread }\end{array}$} & $\begin{array}{l}\text { Kindergarten enrollment rate for three-year preschool } \\
\text { education }(\%)\end{array}$ & 36.4 & 41.4 & 56.6 & 75 & 80 \\
\hline & & Net enrollment rate of primary education $(\%)$ & 99.1 & 99.2 & 99.7 & 99.88 & 100 \\
\hline & & Gross enrollment rate of junior middle school education (\%) & 88.6 & 95 & 100.1 & 104 & 104 \\
\hline & & Gross enrollment rate of senior high school education(\%) & 42.8 & 52.7 & 82.5 & 87 & 90 \\
\hline & & Gross enrollment rate of higher education (\%) & 12.5 & 21 & 26.5 & 40 & 50 \\
\hline & & Number of college students & 910 & 1998 & 2768 & 3647 & 3300 \\
\hline & & Average education year of laborers & 7.85 & 8.5 & 9.9 & 10.23 & 10.8 \\
\hline & \multirow{4}{*}{$\begin{array}{l}\text { Educational } \\
\text { completion } \\
\text { retention }\end{array}$} & Enrollment rate of primary school graduates $(\%)$ & 94.9 & 98.4 & 98.7 & 98 & 100 \\
\hline & & Enrollment rate of junior high school graduates (\%) & 51.2 & 69.7 & 87.5 & 94.1 & 100 \\
\hline & & Enrollment rate of senior high school graduates $(\%)$ & 73.2 & 76.3 & 83.3 & 90.2 & 100 \\
\hline & & Nine-year compulsory education retention rate (\%) & 79.7 & 84.7 & 89.7 & 93 & 95 \\
\hline \multirow{6}{*}{$\begin{array}{l}\text { Educational } \\
\text { condition } \\
\text { security }\end{array}$} & \multirow{3}{*}{$\begin{array}{l}\text { Educational } \\
\text { fund input }\end{array}$} & Proportion of educational fund in GDP $(\%)$ & 4.31 & 4.60 & 4.88 & 5.27 & 7 \\
\hline & & Proportion of state financial educational fund in GDP $(\%)$ & 2.87 & 2.82 & 3.66 & 4.26 & 4.5 \\
\hline & & $\begin{array}{l}\text { Proportion of public financial educational expenditure in } \\
\text { financial expenditure }(\%)\end{array}$ & 13.8 & 14.58 & 15.76 & 14.7 & 16.32 \\
\hline & \multirow{3}{*}{$\begin{array}{l}\text { Educational } \\
\text { information }\end{array}$} & $\begin{array}{l}\text { Proportion of schools equipped with standard facilities for } \\
\text { primary education }(\%)\end{array}$ & 39.93 & 39.91 & 47.64 & 64.5 & 100 \\
\hline & & $\begin{array}{l}\text { Proportion of schools equipped with standard facilities for } \\
\text { junior high school education }(\%)\end{array}$ & 69.65 & 55.2 & 61.67 & 78.7 & 100 \\
\hline & & $\begin{array}{l}\text { Proportion of schools equipped with standard facilities for } \\
\text { senior high school education }(\%)\end{array}$ & 60.27 & 70.05 & 76.95 & 87.1 & 100 \\
\hline \multirow{7}{*}{$\begin{array}{l}\text { Faculty team } \\
\text { construction }\end{array}$} & \multirow{4}{*}{ Faculty input } & Teacher-student ratio in primary education & 22.21 & 19.43 & 17.7 & 17.05 & 16.76 \\
\hline & & Teacher-student ratio in junior high school education & 19.03 & 17.8 & 14.98 & 12.41 & 12.41 \\
\hline & & Teacher-student ratio in senior high school education & 15.87 & 18.54 & 15.99 & 14.01 & 14.01 \\
\hline & & Teacher-student ratio in higher education & 16.3 & 16.85 & 17.33 & 17.73 & 16 \\
\hline & \multirow{3}{*}{$\begin{array}{l}\text { Teachers' } \\
\text { educational } \\
\text { background }\end{array}$} & $\begin{array}{l}\text { Qualification rate of full-time teacher in educational } \\
\text { background for primary education }(\%)\end{array}$ & 96.9 & 98.62 & 99.52 & 99.9 & 100 \\
\hline & & $\begin{array}{l}\text { Qualification rate of full-time teacher in educational } \\
\text { background for junior high school education }(\%)\end{array}$ & 87 & 95.22 & 98.65 & 99.7 & 100 \\
\hline & & $\begin{array}{l}\text { Qualification rate of full-time teacher in educational } \\
\text { background for senior high school education }(\%)\end{array}$ & 68.43 & 83.46 & 94.81 & 97.7 & 100 \\
\hline
\end{tabular}

From 2000 to 2015 , calculation of comprehensive realization of modernized degree can be seen in "Fig 1" and "Table III".

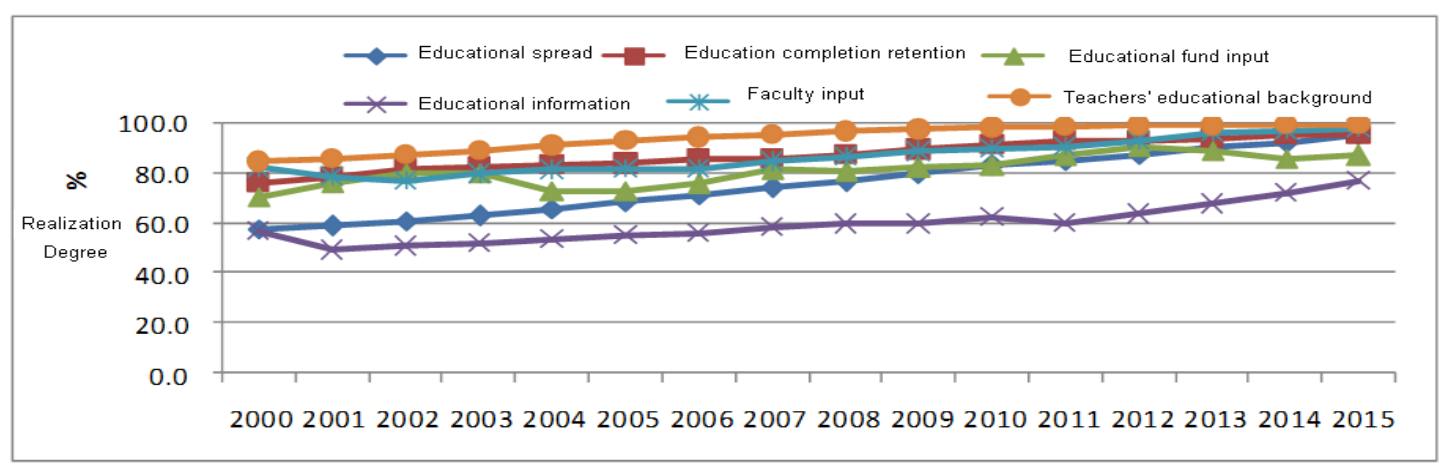

Fig. 1. Realization degree of indices of modernized education (2000 through 2015).

TABLE III. REALIZATION DEGREE OF INDICES OF MODERNIZED EDUCATION (2000 THROUGH 2015)

Unit: \%

\begin{tabular}{l|l|l|l|l|l}
\hline \multicolumn{1}{c|}{ Year } & $\mathbf{2 0 0 0}$ & $\mathbf{2 0 0 5}$ & $\mathbf{2 0 0 8}$ & $\mathbf{2 0 1 0}$ & $\mathbf{2 0 1 5}$ \\
\hline Educational development level & 66.5 & 75.7 & 81.5 & 86.8 & 95.0 \\
\hline Educational condition security & 63.3 & 63.8 & 69.7 & 72.3 & 81.7 \\
\hline Faculty team construction & 82.9 & 87.0 & 91.2 & 93.5 & 98.1 \\
\hline Comprehensive realization degree & 70.9 & 75.5 & 80.8 & 84.2 & 91.6 \\
\hline
\end{tabular}

"Fig 1" and "Table III" show, since 2000, educational development level, educational condition security and faculty team construction all have been greatly improved. From 2000 to 2008 , the comprehensive realization degree of modernized education in China rose to $80.8 \%$ from $70.9 \%$, up about $10 \%$. Of them, the realization degree of educational development level increased at the rapidest speed, increased to $81.5 \%$ from $66.5 \%$, up $15 \%$; the second is the realization degree of educational condition security, increased to $69.7 \%$ from $63.3 \%$, up $6 \%$. From 2008 to 2015 , the comprehensive realization 
degree of basic modernized education reached $91.6 \%$, of which, the realization degree of faculty team construction was the highest, reaching $95.1 \%$ in 2015 . The realization degree of educational development level increased at the rapidest speed, reaching $95.0 \%$ from $81.5 \%$; the second is the realization degree of educational condition security, reaching $81.7 \%$ from $69.7 \%$.

Seen as a whole, from 2000 to 2015, the modernized education had made great progress. However, seen locally, the educational condition security for basic modernized education needs to be improved, we should not only increase educational fund input but also improve the educational information. In addition, educational quality needs to improved, the huge but not strong situation in educational development in China is not changed yet, unbalanced educational development is a serious bottleneck to boost the modernized education, so we must accelerate the educational development system reform, remove barriers blocking the modernized education development, change the current educational development situation, guarantee fair education and balanced development.

\section{CONCLUSION}

The Outline of National Medium-and Long-Term Program for Education Reform and Development (2010-2020) clearly raised work guideline for educational reform and development, namely "Prior development, education-orientated, reform and innovation, promote fairness and improve quality". The 13th five-year plan layout for national economy and social development describes an educational blueprint: up to 2020, China will achieve basic spread of preschool education, and the nine-year compulsory retention rate will rise to $95 \%$; the gross enrollment rate in senior high school education will reach $90 \%$; and the gross enrollment rate in higher education will reach $50 \%$. Seen from the evaluation on modernized education of 2000-2015, the basic realization of modernized education had made great progress. In the future, China's economic development will enter a post-industrialization stage, primary education and middle school education are in a wide spread, and higher education level is improved gradually, and the people will enjoy high quality. From 2016 to 2020, the acceleration of senior high school education and higher education will promote strategic upgrade of education development, and the educational year of laborers will increase continuously. Up to 2020, the proportion of laborers who receive higher education is predicted to exceed $20 \%$, the average educational year will reach 10.8 years, the educational year of newly increased laborers will reach 13.5 years, and it is predicted to achieve the goal of modernized education in China by 2020 or earlier.

\section{REFERENCES}

[1] OECD.Education at a Glance 2010:OECD Indicators[M]. Paris: OECD Publishing,2010.

[2] UNESCO. EFA Global Monitoring Report 2008:Education for All by 2015. Will We Make It[M]. Paris: United Nations Educational, Scientific and Cultural Organization, 2007.

[3] World Bank Group(Ed.). World Development Indicators 2012[M]. Washington: World Bank Publication,2012.
[4] Feng Zengjun, Discussion on Basic Tasks and Main Characteristics of Modernized Education in China [J]. Journal of The Chinese Society of Education, 1995(4):5-8

[5] Zhu Qihong, Nature and Analytical Framework of Modernized Education [J]. Teacher Education Research, 1998(3): 9-13.

[6] Zhou Jiqiu, Ma Weina, Overview of Modernized Education in China since the 9th Five-Year Plan (I) $[\mathrm{J}]$. Journal of Subject Education, 2004(11):1-9.

[7] Zhou Jiqiu, Ma Weina, Overview of Modernized Education in China since the 9th Five-Year Plan (II)[J]. Journal of Subject Education, 2004(12): 6-10.

[8] Gu Mingyuan, Basic Characteristics and Implementation Strategy of Modernized Education [J]. People's Education, 2007(Z2):13-14.

[9] Tan Songhua, Yuan Bentao, Discussion on Indices to Measure Modernized Education [J]. Research On Education Tsinghua University, 2001(1):14-21.

[10] Li Jianning, Pan Sudong, Conception of Setting Index System of Modernized Education [J]. Modern University Education, 2004(1):1116.

[11] Dong Yan, Wang Xiujun, Zhang Yu, Research on Evaluation Index System of Modernized Education Development [J]. Research in Education Development, 2012(21):55-58.

[12] Zhang Li, Research on Statistics and Supervision of Modernized Education in China [J]. Statistics \& Information Forum, 2014,29(10):79-84

[13] Wu Zhihui, Clue and Topic of One Hundred Year Modernized Education Evolution in China $[\mathrm{J}]$. Journal of China University of Geosciences, 2002(4):45-49.

[14] Tian Zhengping, Li Jiangyuan, Educational System Changes and Modernized Education Process in China [J]. Journal of East China Normal University(Educational Sciences), 2002,20(1):39-51.

[15] Tan Songhua, Regional Development of Modernized Education in China [M]. Guangdong: Guangdong Education Publishing House, 2003.

[16] Wang Zhiqiang, Theory of Modernized Education: Evolution and Thought [J]. Journal of National Academy of Education Administration, 2013(10):50-54.

[17] $\mathrm{Hu}$ Angang, Wang Hongchuan, Yan Yilong, Modernized China: Human Resources and Education (1949-2030) [J]. Educational Development Research, 2015(1):9-14.

[18] $\mathrm{Hu}$ Angang, Wang Hongchuan, Yan Yilong, Goal and Index of Modernized Education-Basic Thought for Educational Development in the 13th Five-Year Plan.

[19] Urban Modernized Education Development Evaluation Research Theme Group, Modernized Education Level Supervision Evaluation and Comparative Report in 15 Sub-Provincial Cities in 2014 [R]. National Center for Educational Development Research, 2014. 